\title{
Isolation and characterization of microsatellite loci from the planarian Dugesia polychroa (Schmidt) (Platyhelminthes: Tricladida)
}

\author{
S. RAMACHANDRAN, L. W. BEUKEBOOM, L. GERACE, N. PAVLOVIC, S. CARRANZA and \\ N. K. MICHIELS \\ Arbeitsgruppe Michiels, Max-Planck-Institut für Verhaltensphysiologie, D-82319 Seewiesen, Germany
}

\begin{abstract}
The genomes of many species have been shown to contain loci composed of tandemly repeated short DNA sequences known as microsatellites or simple sequence motifs (Tautz \& Renz 1984). Allelic variation in copy number of the repeat unit renders these loci polymorphic, making them convenient markers for evolutionary studies, including the analysis of population structure (Bruford \& Wayne 1993; Schlötterer \& Pemberton 1994), mating systems and paternity (Queller et al. 1993). We developed microsatellite markers for the free-living fresh water planarian Dugesia polychroa (Platyhelminthes: Tricladida) to study the population structure and mating system of these simultaneously hermaphroditic worms characterized by internal fertilization. Dugesia polychroa has two reproductive biotypes, sexual diploids and pseudogamous parthenogens, which can interbreed to form interbiotype hybrids (Benazzi \& Benazzi Lentati 1976). We developed microsatellites that can be amplified by PCR and used to assay limited amounts of DNA obtained from individual worms. This is the first report on the isolation and characterization of microsatellite loci from a platyhelminth.
\end{abstract}

Genomic DNA from $\approx 100$ worms from the Ammersee, southern Germany, was isolated using a guanidium isothiocyanate method designed for organisms with high nuclease and mucopolysaccharide levels (GarciaFernandez et al. 1993). Three genomic libraries were constructed. The first was made by digesting total genomic DNA with EcoR1 and cloning the resulting fragments into dephosphorylated pUC18 digested with EcoR1. The second library was constructed from size selected fragments according to Rassmann et al. (1991) and cloned into dephosphorylated pUC18 digested with Sma1. Ligation products of both digestions were used to transform E. coli XL1-blue cells (Stratagene), which were plated on

Keywords: ATT repeats, Dugesia polychroa, microsatellite, planarian, platyhelminth, simultaneous hermaphrodite

Received 19 July 1996; accepted 1 October 1996

Correspondence: Dr L. Beukeboom. Tel.: +49-8157-932254 or 232; Fax: +49-8157 932400 or -209. E-mail: beukeboom@mpiseewiesen.mpg.de selective LB media and cultured overnight. Approximately 8000 colonies were transferred into 96-well microtitre plates and replica plated on to nylon membranes (Hybond-N +, Amersham). Colonies were screened with the digoxigenin (DIG) end-labelled (Boehringer Mannheim) synthetic oligonucleotides $(\mathrm{AC})_{8},(\mathrm{AG})_{8}$ $(\text { ASA })_{6},(\text { GACA })_{4},(\text { GATA })_{4},(\text { SAAA })_{4},(\text { SAAT })_{4},(\text { SATT })_{4}$ and (CGCACA) $)_{3}$. Oligonucleotides with identical hybridization temperatures were grouped together (maximum three probes) and used in a single probe cocktail. One clone $D p G A T A 1$ was isolated from the EcoRI pUC18 library. In a second round of screening using $(\mathrm{AT})_{8}$ and $(\mathrm{ATT})_{6}$ as probes, we isolated two (ATT) ${ }_{n}$ clones containing 28 and 47 repeats, respectively, from the size-selected SmaI library.

In addition, a third library was constructed using the charomid vector 9-36 (Saito \& Stark 1986). This vector was chosen because it accepts large inserts (up to $10 \mathrm{~kb}$ ) and uses a recombinant deficient E. coli host N554M in which highly repetitive sequences are stable. Approximately $1 \mu \mathrm{g}$ of genomic DNA was partially digested with EcoRI and ligated into the EcoRI site of the vector. The resulting recombinants were packaged in vitro using Gigapack 11 Packaging extracts (Stratagene) following the manufacturer's instructions. Approximately 3000 colonies of the resultant library, having insert sizes ranging from 3 to $7 \mathrm{~kb}$, were screened with the same probes as previously mentioned. Two clones were recovered with the same (GATA $)_{39}$ microsatellite as above, suggesting that such repeats are rare in the genome. About $30 \%$ of our clones contained ATT repeats, indicating a frequency of approximately one ATT repeat for every $18.5 \mathrm{~kb}$ of the genome. Although $\mathrm{A}+\mathrm{T}$ rich microsatellite sequences have been found in lower organisms such as the slime moulds, fungi, and protists (Field \& Wills 1996), as well as in plants (Powell et al. 1996), ATT microsatellites have not been reported in such high frequencies from any organism.

Eleven clones with strong hybridization signals were selected from the charomid library in order to subclone the smaller positive fragment into SmaI digested pUC 18. Eight of the subclones contained ATT microsatellites which varied in repeat number from 28 to 126 . One clone 
Table 1 Primer sequences and characteristics of Dugesia polychroa microsatellite loci. Number of alleles and size range refer to the length of observed PCR product

\begin{tabular}{|c|c|c|c|c|c|c|c|c|}
\hline Locus & $\begin{array}{l}\text { Repeat } \\
\text { array }\end{array}$ & Primer sequences $\left(5^{\prime}-3^{\prime}\right)$ & $T_{\mathrm{a}}$ & $\begin{array}{l}\text { No. of } \\
\text { ind. }\end{array}$ & $\begin{array}{l}\text { No. of } \\
\text { alleles }\end{array}$ & $\begin{array}{l}\text { Size } \\
\text { range } \\
\text { (bp) }\end{array}$ & $\begin{array}{c}\% \\
\text { heterozygotes }\end{array}$ & $\begin{array}{l}\text { EMBL } \\
\text { Accession } \\
\text { number }\end{array}$ \\
\hline \multirow[t]{2}{*}{ DpGATA1 } & $(\text { GATA })_{39}$ & ATCCACССТTTATTTTACAT & & & & & & \\
\hline & & CATATTGATTTAGTTTGAA & 50 & 176 & 20 & $250-494$ & 34 & X92189 \\
\hline \multirow[t]{2}{*}{ DpATT1 } & $(\mathrm{ATT})_{28}$ & GССТСТСТTTTTAATAA & & & & & & \\
\hline & & TACACATACAATAAAATCC & 55 & 26 & 2 & $146-184$ & 0 & X92191 \\
\hline \multirow{2}{*}{ DpATT2 } & $(\mathrm{ATT})_{44}$ & GCTCAACAACTCGCAAGGG & & & & & & \\
\hline & & GGCATAACAATTTCACACAGG & 60 & 56 & 12 & 29-351 & 30 & X92192 \\
\hline \multirow[t]{2}{*}{ DpATT4 } & $(\mathrm{ATT})_{45}$ & ATCCССАСАAАTATATCTTA & & & & & & \\
\hline & & TCACATTATССТАССССА & 55 & 129 & 12 & 182-301 & 21 & X92194 \\
\hline \multirow[t]{2}{*}{ DpATT7 } & $(\mathrm{ATT})_{28}$ & ССТАСАТТААСССАТTTG & & & & & & \\
\hline & & TGATGATGACAGGAAAACT & 50 & 92 & 18 & $205-256$ & 28 & X92197 \\
\hline \multirow[t]{2}{*}{ DpATT8 } & $(\mathrm{ATT})_{45}$ & TCСССАСАAАТАТАТСТТА & & & & & & \\
\hline & & ССТGTCACATTATCСТАСС & 50 & 73 & 6 & 189-202 & 1 & X92198 \\
\hline \multirow[t]{2}{*}{ DpATT9 } & $(\mathrm{ATT})_{35}$ & TGGGGAAGAACATTGCTA & & & & & & \\
\hline & & AAATAAYCTGTGKGGAAAT & 55 & 30 & 25 & $231-356$ & 77 & X92199 \\
\hline \multirow[t]{2}{*}{ DpAT/AG1 } & $(\mathrm{AT})_{27}(\mathrm{AG})_{16}$ & CCCAAAATGAAATGTAAAG & & & & & & \\
\hline & & CAAAAACGAATAACATAAATA & 55 & 57 & 24 & 186-296 & 61 & X92201 \\
\hline
\end{tabular}

Six microsatellites (EMBL Accession No. X92190, X92193, X92195, X92196, X9200 and X92202) that could not be PCR amplified are excluded

contained three noncontiguous ATT repeats of 32, 10 and 29 units, respectively; one clone a heterogeneous microsatellite with two contiguous regions of the dinucleotide repeats $(\mathrm{AT})_{27}$ and $(\mathrm{AG})_{16}$, and one clone had an $(\mathrm{AG})_{25}$ repeat. PCR primers were designed from the flanking sequences for 12 of these microsatellites (two clones were rejected because in one the flanking region was too short and in the other the sequence was ambiguous) and one primer of each pair was $5^{\prime}$ end-labelled with a fluorescent phosphoramidite dye (6-FAM, TET or HEX, Applied Biosystems). PCR reactions ( $25 \mu \mathrm{L}$ total volume) contained $\approx 50-100 \mathrm{ng}$ of genomic DNA, $10 \mathrm{pmol}$ of each primer, $1 \times$ buffer, $2.5 \mathrm{~mm} \mathrm{MgCl} 2,0.2 \mathrm{~mm}$ each of dNTPs and $0.75 \mathrm{U}$ of Taq polymerase (Promega). Reaction conditions were as follows: an initial denaturation step of $120 \mathrm{~s}$ at $92{ }^{\circ} \mathrm{C}$ followed by 35 cycles of $30 \mathrm{~s}$ at $92{ }^{\circ} \mathrm{C}, 60 \mathrm{~s}$ at the annealing temperature (Table 1) and $60 \mathrm{~s}$ at $72{ }^{\circ} \mathrm{C}$ (except for locus DpATT2 which has a synthesis step at $60^{\circ} \mathrm{C}$ ). All amplifications were performed in a GeneAmp PCR System 9600 thermal cycler (Perkin Elmer) and PCR product lengths were analysed on an ABI 310 Automated Sequencer (Applied Biosystems).

Eight of 12 microsatellites could successfully be amplified from genomic DNA (Table 1). High variability was observed at these loci and heterozygotes were found for all loci examined except DpATT1 and DpATT8. Individuals from several localities including both diploid sexuals and polyploid parthenogens were screened. Numbers of alleles varied from two (DpATT1) to 25
(DpATT9). We are currently using these polymorphic markers to study population structure and mating systems of both reproductive modes of this hermaphroditic species.

\section{Acknowledgements}

We thank D. Tautz for advice, R. Illmensee, D. Lamatsch and J. Zeitlinger for technical assistance and K. Reed and T. Sharbel for comments. S.R. was supported by DFG grant Mi 482/1-1.

\section{References}

Benazzi M, Benazzi Lentati G (1976) Platyhelminthes. In: Animal Cytogenetics 1 (ed. John B). Gebrüder Borntraeger, Berlin-Stuttgart.

Bruford MW, Wayne RK (1993) Microsatellites and their applications to population genetic studies. Current Opinion in Genetics and Development, 3, 939-943.

Field D, Wills C (1996) Long polymorphic microsatellites in simple organisms. Proceedings of the Royal Society of London Series B, 263, 133-240.

Garcia-Fernàndez J, Baguñà J, Saló E (1993) Genomic organization and expression of the planarian homeobox genes Dth-1 and Dth-2. Development, 118, 241-253.

Powell W, Morgante M, Andre C, McNicol JW, Machray GC, Doyle JJ, Tingey SV, Rafalski JA (1995) Hypervariable microsatellites provide a general source of polymorphic DNA markers for the chloroplast genome. Current Biology, 5, 1023-1029.

Queller DC, Strassmann JE, Hughes CR (1993) Microsatellites and kinship. Trends in Ecology and Evolution, 8, 285-288.

(C) 1997 Blackwell Science Ltd, Molecular Ecology, 6, 389-391 
Rassman K, Schlötterer C, Tautz D (1991) Isolation of simplesequence loci for use in polymerase chain reaction-based DNA fingerprinting. Electrophoresis, 12, 113-118.

Saito I, Stark GR (1986) Charomids: Cosmid vectors for efficient cloning and mapping of large or small restriction fragments. Proceedings of the National Academy of Sciences of the USA, 83, 8664-8668.

Schlötterer C, Pemberton J (1994) The use of microsatellites for genetic analysis of natural populations. EXS, 69, 203-214.

Tautz D, Renz M (1984) Simple sequences are ubiquitous repetitive components of eukaryotic genomes. Nucleic Acids Research, 12, 4127-4138. 